\title{
Test means for separate and total determination of heavy metals in aqueous media
}

\author{
(C) Marina K. Gabidulina, Sergey Yu. Doronin, ${ }^{*+}$ and Irina V. Kosyreva \\ Department of Analytical Chemistry and Chemical Ecology. Institute of Chemistry. Saratov State University. \\ Astrakhanskaya St., 81/3. 410012, Saratov.Russia.Phone: +7 (8452)26-45-53. E-mail: Doroninsu@mail.ru
}

$\overline{* \text { Supervising author; }{ }^{+} \text {Corresponding author }}$ Keywords: test means, test methods, heavy metals, integral quality parameters, aqueous media.

\begin{abstract}
The classification of the main indicators of the quality of water bodies is considered. The data on controlled chemical indicators are given (content of dissolved oxygen, suspended solids, phenols, petroleum products, etc.) A list of priority hydrochemical water pollutants and the sources of their pollution are presented. The expediency of determining both individual ions of heavy metals (HM) and their complex (integral) indicators is shown by the example of the sum of HMs. The authors summarized existing data on contemporary test methods used for detection and quantitative measurement of the most prominent HM pollutants of aqueous media, namely - Fe(II), $\mathrm{Fe}(\mathrm{III}), \mathrm{Co}(\mathrm{II}), \mathrm{Ni}(\mathrm{II}), \mathrm{Cu}(\mathrm{II}), \mathrm{Mn}(\mathrm{II})$ and $\mathrm{Al}(\mathrm{III})$ ions. Concentration of such $\mathrm{HM}$ ions can be evaluated by various test means such as indicator papers, detector tubes and polymer plates etc. The main matrices of the test means are considered: cellulose papers, fabrics from artificial and natural fibers, silica gels, xerogels, polymeric materials, etc. The conditions for immobilization and modification of test means (carrying agent, reagent, surfactant, etc.) and principles of analyte determination using the developed test tools (visual and instrumental assessment of the intensity of staining of test forms, determination of the length of staining or bleaching of test tube zones, etc.), as well as some metrological characteristics (detection limit, range of determined contents, relative errors of definitions, etc.) are shown in this article. Detection limits of studied heavy metal ions in aqueous media that can be achieved with proposed test means are as follows: $\mathrm{Fe}$ (II) (0.005-0.01) mg/l; Fe(III) - $0.1 \mathrm{mg} / \mathrm{l} ; \mathrm{Co}(\mathrm{II})-(0.02-0.4) \mathrm{mg} / \mathrm{l} ; \mathrm{Ni}(\mathrm{II})-(0.1-10) \mathrm{mg} / \mathrm{l} ; \mathrm{Cu}(\mathrm{II})-0.05 \mathrm{mg} / \mathrm{l} ; \mathrm{Mn}$ (II) $-0.03 \mathrm{mg} / \mathrm{l} ; \mathrm{Al}(\mathrm{III})-0.02 \mathrm{mg} / \mathrm{l}$; total concentration of several HM ions - $(0.0005-0.001) \mathrm{mg} / \mathrm{l}$.
\end{abstract}

\section{References}

[1] Yu.A. Zolotov. Screening of bulk samples. Journal of Analytical Chemistry. 2001. Vol.56. No.8. P.794. (russian)

[2] Yu.A. Zolotov. About test methods. Journal of Analytical Chemistry. 1996. Vol.51. No.10. P.1029. (russian)

[3] M.I. Evgenyev. Testing methods and ecology. Soros Educational Journal. 1999. No.11. P.29. (russian)

[4] V.A. Mercushev, E.I. Morosanova. Opportunities and prospects for the use of test systems. Partners and competitors. 2005. No.9. P.23. (russian)

[5] Yu.A. Zolotov, V.M. Ivanov, V.G. Amelin. Test methods for extra-laboratory analysis. Trends Anal. Chem. 2002. Vol.21. No.4. P.302.

[6] Yu.A. Zolotov. Recommendations on the terminology of analytical chemistry. Journal of Analytical Chemistry. 2010. Vol.65. No.11. P.1229-1230. (russian)

[7] Yu.A. Zolotov, V.M. Ivanov, V.G. Amelin. Chemical test methods of analysis. Moscow: Editorial URSS. 2002. 304p. (russian)

[8] Sanitary-hygienic standard 2.1.5.1315-03 «The maximum permissible concentration (MPC) of chemicals in the water of water bodies of drinking and household and cultural and social water use». Approved by the Chief State Sanitary Doctor of the Russian Federation 27.04.2003 № 78, int. 15.07.2003. Moscow: Ministry of Health of the Russian Federation. 1998. 77p. (russian)

[9] O.V. Gagarina. Assessment and regulation of the quality of natural waters: criteria, methods, existing problems: study guide. Izhevsk: publishing house «Udmurt University». 2012. 199p. (russian)

[10] A.M. Nikanorov. Scientific basis for water quality monitoring. St. Petersburg: Hydrometeoizdat. 2005. 575p. (russian)

[11] Klein M. V. Some problems of methodological and metrological assurance of water quality control. Works of All-Russia scientific conference with int. participation to the 70th anniversary of the geographical and 20th anniversary of the environmental faculties of Kazan State Univ. Volume IV.

Kazan. The Republic of Tatarstan. Russia. (C) Butlerov Communications. 2019. Vol.57. No.1. 
Environmental Safety, Innovation and Sustainable Development Kazan State Univ. - Kazan. 2009.

P.121-124. (russian)

[12] G.K. Budnikov, G.A. Evtugyn. Rapid test methods for the determination of hydrolytic enzyme inhibitors using electrochemical biosensors. Journal of the Russian Chemical Society. D. I. Mendeleev. 2001. Vol.14. No.4. P.86-94. (russian)

[13] M.V. Dabakhov, E.V. Dabakhova, V.I. Titova. Ecotoxicology and problems of rationing. Nizhny Novgorod State agricultural academy. N. Novgorod: VvAGS Publishing House. 2005. 165p. (russian)

[14] J. Moore, S. Ramamurthy. Heavy metals in natural waters. Moscow: Mir. 1987. 286p. (russian)

[15] Sanitary regulations and standards 2.1.4.1074-01.

[16] Yu.A. Zolotov. Growing opportunities for chemical analysis. Ecology and industry of Russia. 2016. Vol.20. No.3. P.42-46. (russian)

[17] J.R. Baena, M. Valcarcel. Trends Analit. Chem. 2003. Vol.22. No.10. P.641.

[18] V.I. Vershinin, N.A. Isachenko, N.S. Brilenok. Methodology of analysis of unseparated mixtures. Interval estimates of the total content of analytes of the same type. Journal of Analytical Chemistry. 2016. Vol.71. No.4. P.369-376. (russian)

[19] Yu.S. Drugov, A.G. Muravev, A.A. Rodin. Express analysis of environmental samples: a practical guide. Moscow: Binom. Lab knowledge. 2013. 424p. (russian)

[20] K.R. Tarantseva, O.V. Firsova. Comprehensive assessment of the quality of wastewater in the production of cefalexin monohydrate. Chemical and $O \& G$ engineering. 2015. No.9. P.29-32. (russian)

[21] S.Ya. Dvurechenskaya, T.M. Bulycheva. On the question of technical approach to water quality detection by the integral indicators (on the example of Novosibirsk reservoir). Water: chemistry and ecology. 2015. No.10. P.32-37. (russian)

[22] M.A. Fedorova, S.V. Usova, V.I. Vershinin. Accuracy of IR-Spectrometric estimates of the total hydrocarbon content in their model mixtures using different methods for measuring a generalized analytical signal. Analytics and control. 2014. Vol.18. No.1. P.91-98. (russian)

[23] V.G. Amelin. Chemical test methods for determining the components of liquid media. Journal of Analytical Chemistry. 2000. Vol.55. No.9. P.902-932. (russian)

[24] A.G. Aksenova, N.A. Gavrilenko, G.M. Mokrousov. Determination of iron $(2+, 3+)$ with reagents immobilized into a polymethacrylate matrix. Journal "Analytical Chemistry. Laboratory equipment". 2005. No.12. P.175. (russian)

[25] V.N. Losev, S.L. Didukh. Test-systems on the basis of dispersed silicas, modified with polyhexamethylene guanidine and sulfoderivatives of organic reagents for determination of $\mathrm{Cu}, \mathrm{Fe}, \mathrm{Co}$. Journal of Siberian Federal University. Chemistry. 2010. Vol.3. No.1. P.64-72. (russian)

[26] S.L. Didukh, V.N. Losev. Silica fabrics based test systems, modified with polyamine and sulfo derivatives of organic reagents, for iron(II) determination. Journal of Siberian Federal University. Chemistry. 2012. No.5. P.189-197. (russian)

[27] S.L. Didukh, A.N. Mukhina, V.N. Losev. Sorption-photometric and test - determination of total iron in natural waters using zirconium oxide based sorbents, modified with polyhexamethylene guanidine Ferrozine and Ferene S. Analytics and control. 2014. Vol.18. No.4. P.430-437. (russian)

[28] V.G. Amelin, O.B. Chernova. Features of the test reactions of metal ions with chromazurol S immobilized on thin-layer matrices. Journal of Analytical Chemistry. 2008. Vol.63. No.8. P.873-879. (russian)

[29] V.G. Amelin. Test method using indicator papers for the determination of heavy metals in waste and natural waters. Journal of Analytical Chemistry. 1999. Vol.54. No.6. P.651-658. (russian)

[30] E.I. Morosanova, A.A. Velikorodny, I.V. Nikulin, E.A. Puganova, Yu.A. Zolotov. Xerogels modified with 1-(2-pyridylazo)-2-naphtol and xylen orange. Indicator tubes for determining copper(II) and iron(III) in solutions. Journal of Analytical Chemistry. 2000. Vol.55. No.5. P.539-545. (russian)

[31] V.M. Ostrovskaya, L.K. Shpigun, E.A. Reshetnyak, D.O. Shchepilov, G.M. Balak. Indicator tubes based on polydentate hydrazone- and formazan-diasorb for the determination of metals in waters. Water: chemistry and ecology. 2017. No.7. P.72-80. (russian)

[32] N.A. Gavrilenko, N.V. Saranchina, M.A. Gavrilenko. Colorimetric sensor for the determination of cobalt based on a polymethacrylate matrix with immobilized 1-(2-pyridylazo)-2-naphtol. Journal of Analytical Chemistry. 2015. Vol.70. No.12. P.1283-1287. (russian)

[33] R.P. Pantaler, A.K. Timchenko, L.I. Avramenko, A.B. Blank. Rapid test for the determination of cobalt in water. Journal of Analytical Chemistry. 1998. Vol.53. No.5. P.529-532. (russian)

[34] L.M. Coelho, M.A. Bezerra, M.A.Z. Arruda, R.E. Bruns, S.L.C. Ferreira. Determination of Cd, Cu, and $\mathrm{Pb}$ after Cloud Point Extraction using Multielemental Sequential Determination by Thermospray Flame Furnace Atomic Absorption Spectrometry. Sep. Sci. Technol. 2008. Vol.43. P.815-827.

[35] O.Yu. Najafova, S.V. Lagodzinskaya, V.V. Sukhan. Indicator paper for test determination of aluminum 

in solutions. Journal of Analytical Chemistry. 2001. Vol.56. No.2. P.201-205. (russian)

[36] L.V. Gudzenko, R.P. Pantaler, L.I. Avramenko, A.B. Blank. Determination of manganese in drinking water using a rapid test. Journal of Analytical Chemistry. 1996. Vol.51. No.9. P.993-996. (russian)

[37] V.G. Amelin. Test method for determining the total indicators of water quality using indicator papers. Journal of Analytical Chemistry. 2000. Vol.55. No.5. P.532-538. (russian)

[38] V.M. Ostrovskaya, E.A. Reshetnyak, N.A. Nikitina, A.V. Panteleimonov, Yu.V. Kholin. Test method for determining amounts of metals indicator paper and its metrological characteristics. Journal of Analytical Chemistry. 2004. Vol.59. No.10. P.1101-1108. (russian)

[39] E.A. Reshetnyak, V.N. Shevchenko, V.M. Ostrovskaya, Y.A. Bondarenko, E.Yu. Bryleva. Indicator paper for determining the total content of heavy metals in aqueous media. Water: chemistry and ecology. 2015. No.2. P.65-71. (russian)

[40] V.M. Ostrovskaya, L.K. Shpigun, E.A. Reshetnyak, D.O. Shchepilov, G.M. Balak. Indicator tubes based on polydentate hydrazone- and formazan-diasorb for the determination of metals in waters. Water: chemistry and ecology. 2017. No.7. P.72-80. (russian)

[41] Poomrat Rattanarat, Wiiitar Dungchai, David Cate, John Volckens, Orawon Chailapakul, Charles S. Henry. Multilayer paper-based device for colorimetric and electrochemical quantification of metals. Anal. Chem. 2014. Vol.86. P.3555-3562.

[42] G.K. Budnikov. Heavy metals in environmental monitoring of water systems. Sorov Educational Journal. 1998. No.5. P.23-29. (russian)

[43] T.S. Papina. Transport and distribution characteristics of heavy metals in the series: water - suspended matter - bottom sediments of river ecosystems. Ecology. A series of analytical reviews of world literature. 2001. No.62. P.1-58. (russian)

[44] N.A. Shilova. Influence of heavy metals on representatives of freshwater phyto- and zooplankton in saline conditions. Thesis for the degree of candidate of biological sciences. Saratov. 2014. 126p. (russian)

[45] I.V. Savosko. Spectrofluorimetric determination of aluminum (III) using 8-hydroxyquinoline. Chemistry and technology of organic substances, materials and products. 2015. No.4(177). P.90-95. (russian)

[46] I.V. Shugaley, A.V. Garabadzhiu, M.A. Ilyushin, A.M. Sudarikov. Some aspects of the influence of aluminum and its compounds on living organisms. Ecological chemistry. 2012. Vol.21. No.3. P.172186. (russian)

[47] V.M. Martynova. Forms of manganese location, their content and transformation in freshwater sediments. Ecological chemistry. 2012. 21(1). P.38-52. (russian)

[48] J.J. Morgan. Manganese speciation and redox kinetics in natural waters, chemical speciation and reactivity in water chemistry and water technology. Preprints of extended abstracts. 2000. Vol.40. No.2. P.475.

[49] V.Yu. Vishnevetsky, V.M. Popruzhniy. Evaluation of the effect of manganese content in natural water on human health in areas of water intakes in the city of Taganrog. Engineering Bulletin of the Don. 2015. No.4-2(39). P.24. (russian)

[50] S.Yu. Doronin, R.K. Chernova, and A.A. Burmistrova. Extraction concentration of organic analytical forms by systems based on SAS. Butlerov Communications. 2011. Vol.25. No.6. P.94-101. ROI: jbc02/11-25-6-94 